\title{
Reduction of Sink Marks in Injection Overmolding Process of Metal-Plastic Parts
}

Ernest Gondár, Alexander Schrek, Pavol Švec

Faculty of Mechanical Engineering, Slovak University of Technology in Bratislava. Pionierska 15, 83102 Bratislava. Slovak Republic. E-mail: ernest.gondar@stuba.sk, alexander.schrek@stuba.sk, pavol.svec@stuba.sk

Metal-plastic parts with steel inserts prepared by overmolding technique showed several molding defects including sink marks. The depths of sink marks on overmolding metal-plastic parts prepared at two injection overmolding temperatures of 280 and $230{ }^{\circ} \mathrm{C}$ and the same packing pressure of $60 \mathrm{MPa}$ were measured by contact profilometer. They reached the depths of $3.02 \mathrm{~mm}$ and $1.51 \mathrm{~mm}$ at the overmolding temperature of 280 and $230{ }^{\circ} \mathrm{C}$ respectively. These values were correlated with sink marks indexes simulated in Moldflow software at the same conditions. Based on the simulated and measured results the optimal process parameters with injection temperature of 200 ${ }^{\circ} \mathrm{C}$ and packing pressure of $25 \mathrm{MPa}$ were proposed. Simulation showed a positive effect of optimized parameters on sink marks minimizations. Sink marks indexes decreased of $20 \%$ and $53 \%$ compared to injection molding temperatures of 230 and $280{ }^{\circ} \mathrm{C}$ respectively. Maximal depth of sinks marks decreased to the value of $1.00 \mathrm{~mm}$ at optimized injection overmolding process parameters.

Keywords: metal-plastic part, overmolding, sink mark, simulation, residual stress

\section{Acknowledgement}

This article was created with the support of the Ministry of Education, Science, Research and Sport of the Slovak Republic within the Research and Development Operational Programme for the project "University Science Park of STU Bratislava", ITMS 26240220084, co-funded by the European Regional Development Fund.

\section{References}

[1] LUCCHETTA, G., MARINELlO, F., BARIANI, P.F. (2011). Aluminium sheet surface roughness correlation with adhesion in polymer metal hybrid overmolding. In: CIRP Annals - Manufacturing Technology, Vol. 60, pp. 559 - 562. Elsevier, Amsterdam.

[2] SCREIER-ALT, T., REHME, F., ANSORGE, F., REICHL, H. (2011). Simulation and experimental analysis of large area substrate overmolding with epoxy molding compounds. In: Microelectronics Reliability, Vol. 51, pp. 668 - 675. Elsevier, Amsterdam.

[3] ROSSA-SIERA, A., SÁNCHES-SOTO, M., ILLESCAS, S., MASPOCH, M.LI. (2009). Study of the interface behaviour between MABS/TPU bi-layer structures obtained through over molding. In: Materials and Design, Vol. 30, pp. 3979 - 3988. Elsevier, Amsterdam.

[4] PODANÝ, J., MOLOTOVNIK, A. (2014). 3D Measurement of Surface Texture Parameters. In: Manufacturing Technology, Vol. 14, No. 4, pp. 596 - 600. J. E. Purkyne University in Usti nad Labem, Usti nad Labem,

[5] DULEBA, B., GREŠKOVIČ, F. (2012). Application of CA systems at design and simulation of plastic molded parts. In: International Journal of Advanced Engineering Technology, Vol. 3, No. 4, pp. 1 - 7. technicaljournalsonline.com, Durg, India.

[6] CHUN, H.D. (1999). Cavity filling analyses of injection molding simulation: bubble and weld line formation. In: Journal of Materilas Processing Technology, Vol. 89 - 90, pp. 177 - 181. Elsevier, Amsterdam.

[7] EVIN, E., TOMÁŠ, M., VÝBOCH, J. (2012). Prediction of local limit deformations of steel sheets depending on deformation scheme. In: Chemicke Listy, Vol. 106, No. 3, pp. 401 - 404. Czech Society of Chemical Engineering, Praha.

[8] SU, CH., WANG. X. (2014). Sprinkback Research of V-type Sheet Metal forming based on the Adjustable Drawbead and Variable Blank-holder Force Cooperative Control Technology. In: Manufacturing Technology, Vol. 14, No. 4, pp. 618 - 625. J. E. Purkyne University in Usti nad Labem, Usti nad Labem.

[9] GRUJiCIC, V., SEllapPAN, V., PANDURAGAN, B., LI, G., VAHIDI, A., SEYR, N., ERDMANN, M., HOLZLEITNER, J. (2008). Computational analysis of injection-molding residual-stress development in direct adhesion polymer-to-metal hybrid body-in-white components. In: Journal of Materilas Processing Technology, Vol. 203, No. 1 - 3, pp. 19 - 36. Elsevier, Amsterdam. 
[10] SUBA, O, SYKOROVA, L., LUKOVICS, I. (2012). Stress Analysis of Injection - moulded Cylindrical Parts Reinforced with Short Fibres. In: Manufacturing Technology, Vol. 12, No. 13, pp. 254 - 259. J. E. Purkyne University in Usti nad Labem, Usti nad Labem.

[11] GREŠKOVIČ, F., DULEBOVÁ, L'. (2009). Simulation utilization in designing process of injection moulds according to quality. In: Bezpečnost'-Kvalita - Spol'ahlivost', CD ROM, pp. 81 - 84. TU SjF Košice, Košice.

[12] SUN, W., SHAO, J., HE, A., HAO, P. (2015). Research on Distribution of Residual Stresses of Cold Rolled Sheet Distorted Area Based on ANSYS. In: Manufacturing Technology, Vol. 15, No. 2, pp. 220 - 226. J. E. Purkyne University in Usti nad Labem, Usti nad Labem.

[13] GONDÁR, E., SCHREK, A., ŠVEC, P. (2015). Optimization of overmolding process of metal-plastic part. In: Manufacturing Technology, Vol. 15, No. 3, pp. 334 - 339. J. E. Purkyne University in Usti nad Labem, Usti nad Labem.

Copyright (C) 2016. Published by Manufacturing Technology. All rights reserved. 